\title{
ОБЩЕРОССИЙСКАЯ (НАЦИОНАЛЬНАЯ) КОНФЕРЕНЦИЯ «III АКАДЕМИЧЕСКИЕ ЧТЕНИЯ ПАМЯТИ ВЛ. А. ЛУКОВА»
}

\author{
Г. П. Хорина, С. В. Луков \\ Московский гуманитарный университет
}

Аннотация: В статье представлен краткий обзор работы общероссийской (национальной) конференции «III Академические чтения» памяти выдающегося филолога и культуролога Владимира Андреевича Лукова (1948-2014), приуроченные к 5-летию его смерти.

Ключевые слова: обзор; конференция; Московский гуманитарный университет; Вл. А. Луков

\section{ALL-RUSSIAN (NATIONAL) CONFFERENCE “THIRD ACADEMIC READINGS IN MEMORY OF VL. A. LUKOV”}

\author{
G. P. Khorina, S. V. Lukov \\ Moscow University for the Humanities
}

Abstract: The paper presents a brief review of the work of the all-Russian (national) conference "Third Academic Readings" in memory of the outstanding philolo-gist and culturologist Vladimir Andreyevich Lukov (1948-2014), dedicated to his 5-year death anniversary.

Keywords: review; conference; Moscow University for the Humanities; Vl. A. Lukov

4 апреля в Московском гуманитарном университете прошли III Академические чтения памяти выдающегося филолога и культуролога Владимира Андреевича Лукова (1948-2014), приуроченные к 5-летию его смерти. Чтения приобрели статус общероссийской (национальной) конференции и были посвящены теме «Тезаурусы и проблемы культуры». Конференцию приветствовали президент Международной академии наук (IAS) Вальтер Кофлер (его письмо из Австрии представил вице-президент Русской секции Международной академии наук О. С. Глазачев, доктор медицинских наук, профессор Сеченовского университета); директор Среднерусского института управления-филиала РАНХиГС из Орла доктор исторических наук П. А. Меркулов; ректор Национального института бизнеса С. И. Плаксий, доктор философских наук, профессор, заслуженный деятель науки Российской Федерации. 
Научные труды Московского гуманитарного университета 2019 № 2

Выступили профессора А. В. Костина, Е. Н. Шапинская, С. В. Алексеев, И. А. Бирич, В. Н. Захаров (Петрозаводск), видные специалисты философии (А. А. Горелов), культурологии (среди них - видный культуролог Т. Ф. Кузнецова), социологии (в чтениях участвовала А. И. Ковалева, проректор МосГУ, известный социолог), филологии (В. Н. Захаров - президент Международного общества Достоевского, один из ведущих исследователей великого русского писателя и в России, и в мире; профессор В. П. Трыков, авторитетный специалист в области литературоведения и истории журналистики), антропологии (Ч. К. Ламажаа, признанный ученый в данной области), истории (А. И. Фурсов, один из лучших историков), педагогики (в чтениях участвовала Л. В. Романюк, проректор МосГУ по научной деятельности, доктор педагогических наук, профессор) и других областей социального и гума-нитарного знания, исследователи Н. А. Завьялова из Екатеринбурга, О. В. Долженкова из Новосибирска и многие другие. Всего на III Академические чтения были вынесены выступления и материалы участников из таких российских городов - центров науки и образования, как Абакан, Армавир, Барнаул, Белгород, Горно-Алтайск, Екатеринбург, Иркутск, Киров, Кызыл, Магадан, Москва, Новокузнецк, Новосибирск, Орел, Орск, Петрозаводск, Ростов-на-Дону, Рязань, Самара, Санкт-Петербург, Ставрополь, Тольятти, Элиста, Якутск, Ярославль, а также из Инсбрука (Австрия), Эдинбурга (Великобритания).

Многообразие применения тезаурусного подхода хорошо было видно на чтениях: интересные аспекты были найдены в геномной медицине (С. В. Лаврентьева и С. Ю. Шевченко, Институт философии РАН), в шекспиросфере и марлосфере (Н. В. Захаров, Шекспировский центр ИФПИ МосГУ), в самых разных областях гуманитарного знания. Эта широта тематики - где рядом оказались раннее Средневековье балканских стран и биосоциология как становящееся направление социологии молодежи; непознанные черты творчества Ф. М. Достоевского и новые американские и британские фильмы и оперные постановки по мотивам пушкинского «Евгения Онегина», позволяющие судить о том, как образ России понимается культурными кругами Запада; нынешнее проникновение в традиционную культуру Китая знаков англосаксонской цивилизации и исследования концептов тувинской культуры, - показывает, что тезаурусный подход, возникший как методологическая новация в области литературоведения, а потом ставший методологической основой издательского проекта «Всемирная Детская Энциклопедия “Глобус"» (поддержанного норвежским путешественником Туром Хейердалом, шведской писательницей Астрид Линдгрен, президентом Академии наук Украины Б. Патоном, деятелями культуры России - исследователем русской литературы Дмитрием Лихачевым, кинорежиссером и актером Роланом Быковым, поэтом Расулом Гамзатовым, многими академиками, профессорами, детскими и молодежны- 
ми организациями по всему миру), в годы работы Владимира Андреевича Лукова в Институте фундаментальных и прикладных исследований МосГУ приобрел черты общенаучной методологии. III Академические чтения это еще раз доказали. Это было показано и в выступлениях директора ИФПИ, доктора философских наук и доктора культурологии А. В. Костиной, которая вела конференцию, и в основном докладе Вал. А. Лукова, доктора философских наук, профессора, соавтора многих работ Вл. А. Лукова по выстраиванию системы тезаурусного подхода.

Выступления участников и присланные материалы будут опубликованы в сборнике материалов конференции, в журнале «Знание. Понимание. Умение», так что с итогами чтений ознакомится большой круг ученых - российских и зарубежных.

Дата поступления: 08.04.2019 2.

Хорина Галина Петровна - доктор философских наук, профессор, профессор кафедры истории и регионоведения Московского гуманитарного университета. Адрес: 111395, Россия, г. Москва, ул. Юности, д. 5. Тел.: +7 (499) 374-70-88. Эл. адрес: galhorina@mail.ru

Луков Сергей Валерьевич - кандидат социологических наук, началь-ник научно-исследовательского отдела прикладной социологии Центра со-циологии молодежи Института фундаментальных и прикладных исследований Московского гуманитарного университета. Адрес: 111395, Россия, г. Москва, ул. Юности, д. 5. Тел.: +7 (499) 374-75-95. Эл. адрес: sv-lukov@mail.ru

Khorina Galina Petrovna, Doctor of Philosophy, Professor, Professor, Department of History and Regional Studies, Moscow University for the Humanities. Postal address: 5, Yunosti St., Moscow, Russian Federation, 111395. Tel.: +7 (499) 374-7088. E-mail: galhorina@mail.ru

Lukov Sergey Valeryevich, Candidate of Sociology, Head, Research and Development Department for Applied Sociology, Centre for Sociology of Youth, Institute of Fundamental and Applied Studies, Moscow University for the Humanities. Postal address: 5, Yunosti St., Moscow, Russian Federation, 111395. Tel.: +7 (499) 374-7595. E-mail: sv-lukov@mail.ru

\section{Для цитирования:}

Хорина Г. П., Луков С. В. Общероссийская (национальная) конференция «III Академические чтения памяти Вл. А. Лукова» [Электронный ресурс] // Научные труды Московского гуманитарного университета. 2019. № 2. URL: http://journals.mosgu.ru/trudy/article/ view/966 (дата обращения: дд.мм.гг.). DOI: 10.17805/trudy.2019.2.9 